Journal of the Optical Society of Korea, Vol. 16, No. 3, pp. 288-291 September 2012

\title{
Design of Ultra-Wide Band-Pass Filter Based on Metamaterials Applicable to Microwave Photonics
}

\author{
Chongmin Lee, Wooseok Shim, Yong Moon*, and Chulhun Seo \\ School of Electronic Engineering, College of Information Technology, Soongsil University, \\ 511 Sangdo-dong, Dongjak-gu, Seoul 156-743, Korea
}

※ The acknowledgment of the paper,"Design of Ultra-wide Band-Pass Filter Based on Metamaterials Applicable to Microwave Photonics” published in September 2012 (Vol. 16, No. 3) should be corrected as follows;

\section{ACKNOWLEDGMENT}

This work was supported by the Human Resources Development Program(No. 20124010203160) of the Korea Institute of Energy Technology Evaluation and Planning (KETEP) grant funded by the Korea Government Ministry of Knowledge Economy and by the National Research Foundation of Korea (NRF) grant funded by the Korea government (MEST) (No. 20120008842).

\begin{tabular}{|c|c|c|}
\hline 전 & 후 & 사유 \\
\hline & $\begin{array}{c}\text { This work was supported by the } \\
\text { Human Resources Development } \\
\text { program (No. 20124010203160) } \\
\text { of the Korea Institute of Energy }\end{array}$ \\
This work was supported by & Technology Evaluation and & Planning(KETEP) grant funded by \\
the Soongsil University & 저자의 과오로 인한 \\
Research Fund of 2009. & 과제번호 표기누락 및 \\
& Knowledge Economy and by the & 재정지원 기관 명료화 \\
& National Research Foundation of & \\
& Korea(NRF) grant funded by the & \\
& Korea government(MEST) & \\
& (No. 20120008842). & \\
\hline
\end{tabular}

